\title{
Kekerasan Simbolik Dalam Tradisi Perkawinan Masyarakat Tolaki Sulawesi Tenggara
}

\author{
Asliah Zainal ${ }^{1)}$; Sudarmi Suud ${ }^{2)}$ \\ ${ }^{1)}$ Fakultas Ushuluddin, Adab, dan Dakwah Institut Agama Islam Negeri Kendari; ${ }^{2)}$ Fakultas \\ Keguruan dan Ilmu Pendidikan Universitas Haluoleo Kendari
}

Corresponding Author: liazain03274@gmail.com

\begin{abstract}
The position of customary institutions in traditional societies has two faces; be a protector and solution for the community, but can also be a dominant and even compelling force. This study will examine the marriage traditions of the Tolaki community that move between apparent compromise and potential conflict. Indigenous marriages implicitly indicate a form of symbolic violence that constructs false compromise in Tolaki society as well as potential latent conflicts. Symbolic violence can be found in several forms, namely injustice in the opportunity to marry women from any group; and rejection of procedures and marriage procedures. This condition is caused by social differences in the community; there is no legitimacy of the crime and the same opportunities; differences in interests between various parties; and the dominance of the indigenous elite. However, the marriage practices of the Tolaki community bring change with the loosening of the system and the social structure of the Tolaki community which was originally "closed." This can open up equal opportunities for all segments of society to get a life partner so that a more egalitarian society can be created.
\end{abstract}

Keywords: conflict; compromise; customary institutions; marriage traditions; symbolic violence

\begin{abstract}
Abstrak
Posisi lembaga ada dalam masyarakat tradisional memiliki dua wajah; menjadi pelindung dan rujukan solutif bagi masyarakat, tetapi juga bisa menjadi kekuatan dominan bahkan memaksa. Studi ini akan mengkaji tradisi perkawinan masyarakat Tolaki yang bergerak diantara kompromitas semu dan konflik laten. Adat perkawinan secara implisit mengindikasikan bentuk kekerasan simbolik yang mengkonstruk kompromitas semu dalam masyarakat Tolaki sekaligus konflik laten yang potensial. Kekerasan simbolik dapat ditemui dalam beberapa bentuk, yaitu ketidakadilan dalam kesempatan menikahi perempuan dari golongan manapun; dan penolakan terhadap prosedur dan tatacara perkawinan. Kondisi ini disebabkan oleh perbedaan kelas sosial dalam masyarakat; tidak ada legitimasi atas hak dan peluang yang sama; perbedaan kepentingan antara berbagai pihak; dan dominasi elit adat. Bagaimanapun, praktek perkawinan masyarakat Tolaki membawa perubahan dengan longgarnya sistem dan struktur sosial masyarakat Tolaki yang semula "tertutup". Hal ini dapat membuka peluang yang sama bagi semua golongan masyarakat dalam mendapatkan pasangan hidup sehingga tercipta masyarakat yang lebih egaliter.
\end{abstract}

Kata Kunci; lembaga adat, kekerasan simbolik, konflik, kompromitas, tradisi perkawinan. 


\section{A. Pendahuluan}

Mengkaji budaya masyarakat selalu saja menarik terutama jika melihatnya pada konstruksi kultural dan implikasinya bagi sistem dan struktur masyarakat itu sendiri. Konstruksi kultural ini juga bisa dilihat melalui tradisi perkawinan dalam masyarakat. Perkawinan adalah salah satu upacara daur hidup yang memiliki tata cara, tahap-tahap dan persyaratan yang sangat detil bahkan ketat. Perkawinan dalam masyarakat Tolaki merupakan upacara adat yang mengandung ritual khusus mulai pra-perkawinan, proses perkawinan, sampai pasca-perkawinan. Perkawinan menurut masyarakat Tolaki tidak saja menjadi urusan calon mempelai dan keluarganya, tetapi juga melibatkan lembaga adat, pemerintah, bahkan masyarakat secara keseluruhan.

Tradisi perkawinan yang sejatinya menyatukan dua keluarga dalam satu rumpun keluarga besar, dalam beberapa kasus mengandung konflik dan pertentangan, hanya saja konflik demikian tidak terlalu terlihat secara kasat mata atau bahkan tidak disadari oleh pelakunya. Dalam konteks ini telah terjadi gejala kekerasan simbolik dalam masyarakat. Kekerasan simbolik (Symbolic violence) mengarah pada manipulasi kewajiban dengan menggunakan simbol-simbol budaya setempat ${ }^{1}$. Tulisan ini bukan ingin mengungkap aspek lain dari sebuah praktek budaya (khususnya dalam perkawinan), tetapi hanya ingin memotret sebuah fenomena sosial kultur masyarakat yang boleh jadi memang diperlukan demi kemapanan struktur dan stabilitas masyarakat itu sendiri. Hal ini diperlukan mengingat bahwa "protes-protes sosial" yang muncul dalam banyak kasus perkawinan masyarakat Tolaki sedikit banyak telah memunculkan sistem masyarakat yang lebih egaliter dan membiarkan atau mengizinkan perbedaan status sosial "terjembatani" dalam kebolehan menikahi perempuan dari status sosial lebih tinggi tanpa harus terbebani syarat adat.

Beberapa penelitian sebelumnya yang menyoroti tentang kekerasan simbolik dalam praktek kebudayaan diantaranya adalah Hamdi dalam artikelnya "Tuan Guru, Otoritas, Politik Dan Reproduksi Kekerasan-Ritual Dalam Konflik Nahdlatul Wathan Di Lombok NTB". ${ }^{2}$ Studi ini menemukan bahwa tuan guru yang merupakan gelar tertinggi dalam masyarakat Lombok ikut mengambil peran baik secara struktural maupun kultural dalam konflik Nahdlatul Wathan (NW). Dengan otoritas keilmuan yang dimilikinya, para tuan guru menggunakan kekerasan dalam bentuk legitimasi religius untuk melawan pihak lain yang notabene adalah saudara sendiri. Keterlibatan pemimpin agama dalam situasi kekerasan juga terjadi di masyarakat Madura sebagaimana penelitian yang dilakukan oleh Hefni yang meneliti tentang "Tradisi Mawlid dan Kekuasaan Smbolik Kyai Di Madura". ${ }^{3}$ Penelitian ini menemukan bahwa dengan kekuasaan simbolik yang dimilikinya, Kiyai di Madura melakukan penafsiran ulang atas makna maulid sehingga ajaran ini menjadi ajaran ortodoxy yang diikuti oleh sebagian besar masyarakat Madura, hingga perayaanya melebihi kemeriahan perayaan idul fitri. Masih dalam setting sosial masyarakat Madura, penelitian dilakukan oleh Rozaki yang menulis tentang "Social Origin dan Politik Kuasa Blater di Madura". ${ }^{4}$ Penelitian ini menemukan bahwa blater di madura digunakan oleh figur lokal (termasuk para kiyai) untuk

${ }^{1}$ Riches, D, "The Phenomenon of Violence" Dalam The Anthropology of Violence, disunting oleh D. Riches, (Oxford: Blackwell, 1986), h. 22; Lihat pula Schroder, I.W dan B.E. Schmidt. 2001. "Introduction: Violence Imaginaries and Violence Practice. Dalam Anthropology of Violence and Conflict, disunting oleh I.W. Schmidt dan B.E. Schroder. (London: Routledge, 2001), h. 6.

2 Saipul Hamdi, "Tuan Guru, Otoritas, Politik Dan Reproduksi Kekerasan-Ritual Dalam Konflik Nahdlatul Wathan Di Lombok NTB". Tp.

${ }^{3}$ Moh. Hefni, Moh, "Tradisi Mawlid Dan Kekuasaan Simbolik Kyai Di Madura”. Jurnal Nuansa, Vol 10, No. 2 (Juli-Desember, 2013): 314-334.

4 Abdur Rozaki, "Social Origin dan Politik Kuasa Blater di Madura", Kyoto Review of Southeast Asia, Issue 11 (December 2009). 
mendulang kekuasaan dan pengaruh dalam masyarakat dan juga menegaskan bahwa penguasa di Madura hampir seluruhnya memiliki akar kultural-religius yang cukup kuat. Studi tentang peran elit lokal dalam praktik beragama ditemukan dalam studi yang dilakukan Rais tentang "Hegemoni Elit Dalam Ritus Agama Lokal: Studi Keberagamaan Masyarakat Bugis Bone Sulawesi Selatan". 5 Penelitian ini menjelaskan bahwa sanro atau dukun lokal di masyarakat Ujung Sulawesi Selatan yang memiliki relasi kuasa atas kultur lokal melakukan hegemoni atas ritual-ritual keagamaan, sehingga lebih dominan dari pada tokoh agama itu sendiri.

Penelitian Hamdi, Hefni, Rozaki, dan Rais mengambil fokus pada keterlibatan pemimpin kultural-religius yang menguasai sumber-sumber dan legitimasi kekuasaan secara kultural-religius bagi posisinya di masyarakat_bahkan dalam bidang politik_menggunakan simbol-simbol agama untuk menguatkan pengaruh dan dominasinya. Tanpa mengabaikan penelitian-penelitian sebelumnya, fokus penelitian ini diarahkan pada konstruksi sosial budaya yang melingkupi kebudayaan Tolaki dalam tradisi perkawinanya yang didalamnya terimplikasi adanya kekerasan simbolik lewat legitimasi simbol-simbol adat istiadat. Berbeda dengan penelitian sebelumnya yang menfokuskan pada keterlibatan agama dalam peran-peran figurnya (penelitian Hamdi, Hefni, dan Rozaki), dan juga melibatkan simbol agama untuk menguatkan peran elit lokal (penelitian Rais), penelitian ini menegaskan pertentangan praktek adat dengan agama, khususnya dalam pelaksanaan perkawinan. Dengan fokus studi tersebut, tulisan ini akan melihat bagaimana tradisi perkawinan masyarakat Tolaki menampakkan wajah konflik tersembunyi sebagai bentuk kekerasan simbolik atau kekerasan struktural yang bekerja dalam simbol-simbol adat demi stabilitas masyarakat. Tulisan ini juga mengkaji bagaimana kekerasan simbolik tersebut mendapatkan "perlawanan" dalam masyarakat sehingga secara perlahan-lahan mengkonstruk sistem masyarakat yang lebih terbuka.

Kasus perkawinan masyarakat Tolaki diharapkan dapat membangun pemahaman bahwa perselisihan atau konflik bukan menunjukkan suatu kondisi disharmonis dan sebaliknya, stabilitas dan integrasi akibat adanya kompromitas tidak juga berarti stabilitas yang mapan, tanpa ada riak konflik di dalamnya. Bahkan, seringkali ditemui, stabilitas yang disuguhkan masyarakat bukan karena ada konsensus yang disetujui secara bersama, tetapi lebih karena ada unsur pemaksaan oleh kekuasaan tradisional agar konflik tidak sempat tercetus. Kepatuhan dan keteraturan dalam masyarakat bisa saja berarti stabilitas yang mapan, tetapi bisa pula menggambarkan stabilitas yang dipaksakan.

\section{B. Tradisi Perkawinan Masyarakat Tolaki}

Masyarakat Tolaki adalah salah satu suku besar yang sebagian besar mendiami dua kabupaten di Sulawesi Tenggara, yaitu Kabupaten Konawe yang secara historis merupakan bekas kerajaan Konawe dan Kabupaten Kolaka yang merupakan bekas kerajaan Mekongga. Meskipun secara geografis orang Tolaki mendiami dua tempat yang berbeda, namun dalam praktek dan pemahaman adat istiadat, masyarakat kedua wilayah ini memiliki persepsi yang sama, khususnya dalam adat perkawinan. Mereka adalah sama-sama orang Tolaki yang berasal dari satu nenek moyang (tolaki mbuupuu) yang secara kebetulan dipisahkan oleh wilayah kekuasaan.

Struktur masyarakat Tolaki ditentukan oleh faktor geneologis secara patrineal dengan kombinasi peran bapak dan ibu dalam menghitung garis keturunan, disamping faktor teritorial yang ikut menentukan struktur masyarakat desa dan masyarakat wilayah gabungan dari beberapa desa. Sistem kekerabatan ditentukan oleh keluarga batih (o rapu) yang berarti

\footnotetext{
${ }^{5}$ Muhammad Rais, "Hegemoni Elit Dalam Ritus Agama Lokal: Studi Keberagamaan Masyarakat Bugis Bone Sulawesi Selatan”. Jurnal el-Harakah, Vol. 12, No. 2 (2010): 99-119.
} 
rumpun pohon yang bermakna rumpun keluarga. ${ }^{6}$ Seseorang yang melangsungkan perkawinan, berarti ia merapu atau membentuk rumpun atau rumah tangga baru. Keluarga batih ini juga berimplikasi pada perkawinan, khususnya dalam menentukan perempuan yang boleh dan tidak boleh dinikahi. Karena itulah, perkawinan dalam masyarakat Tolaki sangat menentukan terbentuknya struktur masyarakat yang berasal dari keluarga batih tersebut.

Masyarakat Tolaki pada masa lalu mengenal sistem pelapisan sosial yang diwarisi dari masa pemerintahan kerajaan Konawe dan kerajaan Mekongga. Pembedaan/pengelompokkan masyarakat didasarkan atas keturunan dan kepemilikan tanah. Sistem pelapisan sosial dikenal ada tiga, yaitu lapisan bangsawan (anakia) dikenal dengan istilah pu'onu o kasu (induk pohon), yang berarti pelindung atau pemimpin; lapisan penduduk asli, pemilik negeri (too wonua) dan disebut toono motuo (orang yang dituakan) atau ata wonua (hamba negeri), yang berarti abdi negara, rakyat biasa, penduduk (toono dadio); dan golongan budak atau hamba sahaya (ata). ${ }^{7}$ Penggolongan masyarakat tersebut berpengaruh cukup besar dalam pergaulan sehari-hari, termasuk adat perkawinan. Hal ini bisa dilihat dari adanya larangan kawin antara golongan yang satu dengan golongan lainnya.

Perkawinan masyarakat Tolaki bukanlah perkara yang cuku p bisa diputuskan oleh calon pengantin itu sendiri ataupun keluarganya, tetapi melibatkan pula para tokoh adat, bahkan masyarakat pada umumnya. Keterlibatan keluarga dalam menentukan keputusan perkawinan menyangkut prestise, nama baik, dan harga diri keluarga. Keterlibatan para tokoh adat menjadi sesuatu yang penting dan sentral, sebab secara langsung mereka terlibat dimulai saat sebelum terjadinya perkawinan sampai pada perkawinan itu sendiri, bahkan setelah perkawinan. Hal ini didasarkan pada dasar utama perkawinan adalah kesepakatan bersama antarkeluarga, atau yang disebut dengan "ano pada poehenoki pada anamotuo", artinya haruslah atas dasar kesepakatan bulat dari keluarga masing-masing pihak.

Masyarakat Tolaki memiliki falsafah pernikahan yang menganjurkan menikah dengan keluarga dekat (maatopelangguako esipi ano issue moaru-oru kiniwia, taneonggo teposinggalako mata pute ano mata meeto) artinya, meskipun berselisih pagi dan sore, mata putih dan mata hitam tidak akan terpisahkan. Ungkapan ini mengandung makna bah wa dalam perkawinan meskipun sering berselisih/bertengkar, tetapi persaudaraan di antara mereka tidak akan terputus. Maka, asas pemlihan jodoh dengan mendahulukan keluarga dekat (endogami) menjadi sesuatu yang dianjurkan. Perkawinan seperti ini disebut dengan merapu ndonomeohai atau mombokai peohai'a (untuk mempererat tali persaudaraan), dan mekaputi (ikat mengikat). Banyak hal yang dapat digali dari falsafah tersebut. Pertama, mengantisipasi agar harta kekayaan tidak jatuh pada pihak di luar keluarga; kedua, potensi dan integrasi keluarga asal dari satu nenek moyang tetap terbina dan dipertahankan; ketiga, hubungan darah/keturunan tetap terpelihara, khususnya bagi keturunan bangsawan. Meskipun demikian, tidak tertutup kemungkinan masyarakat Tolaki juga mengenal perkawinan di luar keluarga dekat (exogami) yang biasa disebut dengan merapu ndoono suere (kawin dengan orang lain).

Perkawinan dalam masyarakat Tolaki disebut dengan mowindahako yang berarti penyerahan materi adat (popolo, materi adat pokok, dan lain- lain) kepada pihak perempuan melalui juru bicara. Praktiknya, sebelum pesta perkawinan, pihak keluarga laki-laki lebih dahulu menyerahkan biaya pesta, beras dan sapi/kerbau kepada keluarga perempuan sesuai yang disepakati dalam acara peminangan (mowawo niwule). Materi pokok adat baru

${ }^{6}$ Lihat Abdur Rauf Tarimana, Kalo Sebagai Fokus Kebudayaan Tolaki. Disertasi di Universitas Indonesia, (Jakarta: Universitas Indonesia, 1985), h. 142; lihat pula Tim, Adat dan Upacara Perkawinan Daerah Sulawesi Tenggara, (Jakarta: Proyek Penelitian dan Pencatatan Kebudayaan Daerah Sulawesi Tenggara, 1978/1979), h. 20.

${ }^{7}$ Abdur Rauf Tarimana, Kalo sebagai..., h.199. 
diserahkan kepada pihak perempuan pada waktu upacara perkawinan dilangsungkan dengan disaksikan seluruh tamu dan keluarga besar kedua belah pihak.

Materi adat yang harus dibawa pada acara mowindahako adalah (a) Popolo atau mas kawin yang disesuaikan dengan derajat sosial perempuan, (b) pokok adat (puuno Sara), terdiri atas satu pis kain kaci, satu ekor kerbau atau kiniku yang bisa diuangkan, satu buah gong atau tawu-tawu yang bisa diuangkan, satu untai kalung adat atau oeno yang bisa diuangkan, (c) pelengkap (tawano sara) berupa 8 atau 16 lembar sarung (disesuaikan dengan derajat sosial perempuan yang akan dinikahi), (d) sarapeana berupa satu buah baskom untuk mandi bayi (bokumbebahoa), satu buah timba air (sandusandu), satu buah lampu tembok (sikuhulo), satu lembar kain sarung (rane-ranembaa), satu kain gendongan untuk menggendong bayi. Berikut ini akan diuraikan satu persatu.

\section{Popolo}

Popolo adalah salah satu persyaratan adat yang harus dipenuhi dalam perkawinan. Bentuk popolo pada masa kerajaan Konawe dan Mekongga adalah mata uang (koin) Buton yang disebut dengan oboka atau okufa. Pada perkembangan selanjutnya, koin tersebut diganti dengan kerbau (kiniku). Dewasa ini, popolo beralih bentuk dalam wujud uang rupiah sebagai bentuk interprestasi real, mata uang Arab ditambah dengan sarung plekat (o 'lipa).

Jumlah popolo yang harus dibayarkan oleh keluarga laki-laki ditentukan oleh beberapa hal, yaitu 1) derajat dan kedudukan sosial orang tua calon mempelai perempuan beserta keluarganya, 2) besar kecilnya jumlah mahar (popolo) yang dibayarkan kepada ibu calon mempelai perempuan sewaktu menikah dahulu, 3) latar belakang bentuk perkawinan, dan 4) kesepakatan keluarga kedua belah pihak dan hasil sidang adat kalosara (sarawonua). Penentuan jumlah popolo tidak hanya ditentukan oleh derajat sosial perempuan dan orang tua perempuan, tetapi juga oleh keseluruhan rumpun keluarga. Bisa saja, perempuan tersebut lemah secara ekonomi, tetapi karena keluarga besanya adalah bangsawan, maka dianggap suatu kewajaran bila keluarga perempuan meminta popolo dan biaya pesta yang cukup tinggi. Sebab jika tidak, maka, keluarga secara keseluruhan akan merasa direndahkan dan terhina.

\section{Ad. 1 Derajat dan kedudukan sosial orang tua dalam masyarakat}

Kedudukan dan jabatan orang tua si gadis menentukan besar kecilnya popolo yang harus dipenuhi oleh keluarga pihak laki-laki yang dituangkan dalam ungkapan oka- oka peree-rehuno anomotuono o'tina. Semakin tinggi derajat sosial dan jabatan orang tua si gadis, maka jumlah popolo akan semakin besar pula. Secara umum, ketentuan popolo adalah sebagai berkut;

a. Bila orang tua si gadis adalah dari golongan bangsawan murni (ayah dan ibu sama-sama dari golongan anakia), maka popolonya adalah 88 real tunai atau diganti dengan jumlah rupiah senilai kurs real yang berlaku; 40 atau 80 lembar sarung plekat halus, seperangkat alat sholat (sebagai bentuk mahar secara Islam).

b. Bila orang tua si gadis dari golongan menengah (toonomotuo) atau hanya sebagian kebangsawanannya (entah dari garis ayah atau ibu), maka kadar popolonya adalah 80 real tunai atau bisa diuangkan, 16-20 lembar sarung plekat, seperangkat alat sholat (sebagai mahar secara Islam).

c. Bila orang tua si gadis berasal dari rakyat biasa, maka popolonya adalah 40 real, 5 lembar sarung, seperangkat alat sholat ( sebagai mahar secara Islam)

Dewasa ini, ketentuan tersebut tidak lagi dipraktekkan secara ketat. Golongan bangsawan dan rakyat biasa hanya tinggal nama dan tidak lagi dibedakan hanya berdasarkan keturunan semata, tetapi lebih pada pertimbangan pendidikan dan kontribusi yang diberikan kepada masyarakat. Dengan demikian, kadar popolo tidak lagi terlalu mengikat sebagaimana ketentuan adat awalnya, yaitu besar kecilnya ditentukan oleh derajat 
sosial kebangsawanan orang tua si gadis semata. Kadar popolo tersebut sudah mengalami pergeseran dengan diberlakukannya ketentuan popolo sejumlah 88 real untuk semua golongan masyarakat secara merata. Namun demikian, dalam banyak kasus di desa-desa masih dijumpai hal demikian.

\section{Ad.2 Besar kecilnya jumlah mahar (popolo) ibu si gadis pada saat menikah dulu}

Jumlah dan bentuk popolo yang harus dibayar oleh pihak laki-laki harus pula mempertimbangkan jumlah dan bentuk popolo ibu si gadis yang diperoleh dahulu sewaktu menikah yang dibahasakan dengan mbee-mbee popolono inano, maa nggoieikaa itoono nggo popolono amano. Ketentuan tersebut ditetapkan dalam upaya menjaga nama baik dan kehormatan keluarga. Jika ayah si gadis dahulu sewaktu menikahi ibunya belum memenuhi adat yang mestinya harus dibayarkan, maka si gadis sekarang dan juga keluarganya tidak berhak untuk meminta popolo dan biaya pesta, karena dianggap tidak beradab dan tidak menghormati adat. Hal semacam ini disebut dengan ule ndaanio sarano. Persyaratan demikian mencerminkan betapa kuatnya pengaruh keturunan dalam adat Tolaki. Keturunan dan nama baik keluarga merupakan poin penting yang harus selalu dijunjung tinggi oleh seluruh klan orang Tolaki.

Ad.3 Latar belakang bentuk perkawinan

Besar kecilnya kadar popolo tergantung atas latar belakang bentuk perkawinan: melalui proses normal atau tidak normal (melanggar adat), seperti kawin lari, melarikan tunangan atau isti orang, dan sebagainya. Jika perkawinan dilakukan dengan cara pinangan, maka jumlah popolo yang harus dipenuhi sesuai dengan ketentuan adat yang berlaku. Sebaliknya, jika perkawinan melanggar adat yang ditempuh, maka popolo yang dibayarkan bisa saja berkurang atau bahkan bertambah banyak sesuai kesepakatan keluarga dan sidang adat.

\section{Ad.4 Kesepakatan keluarga kedua belah pihak dan hasil sidang adat sarawonua}

Adat istiadat telah menggariskan kadar dan bentuk popolo yang harus dipenuhi pihak keluarga laki-laki, sesuai dengan pertimbangan-pertimbangan di atas. Tetapi, di luar semua itu, yang menentukan secara persis jumlah dan bentuknya adalah hasil kesepakatan keluarga kedua belah pihak dan sidang adat.

Pihak keluarga laki-laki boleh saja mengajukan keberatan terhadap jumlah popolo dan biaya pesta, seperti yang diminta keluarga perempuan, jika tidak mampu. Keberatan tersebut dapat dimusyawarahkan bersama secara tertutup antara kedua orang tua calon mempelai. Maka, kesepakatan kedua belah pihak dengan cara musyawarah tetap merupakan pertimbangan utama dalam perkawinan, sebab perkawinan dalam masyarakat Tolaki terkait erat dengan nama baik, kehormatan dan prestise keluarga kedua belah pihak. Seringkali yang terjadi adalah, kemampuan keuarga laki-laki dalam membayar uang adat tidak sampai memenuhi permintaan keluarga perempuan, akan tetapi demi menjaga kehormatan dan nama baik keluarga (agar tetap dipandang bermartabat), maka yang disebut dalam prosesi adat adalah jumlah yang diminta (meskipun keluarga laki-laki tidak mampu memenuhinya).

\section{Pokok adat (puuno sara)}

Puuno sara atau pohonya adat merupakan pokok adat yang harus ada dalam perkawinan orang Tolaki. Isi puuno sara tersebut pada zaman kerajaan Konawe dan Mekongga dalam wujud benda yang terdiri atas; 1 pis kain kaci, 1 ekor kerbau, 1 buah gong, dan 1 untai kalung eno. Karena benda-benda tersebut dewasa ini praktis sudah sulit untuk didapatkan, maka lembaga adat menetapkan bahwa boleh diganti dengan uang rupiah. Jumlah rupiah yang ditetapkan disesuaikan dengan kurs rupiah yang berlaku sekarang.

\section{Tawano Sara}


Tawano sara adalah pelengkap pokok adat. Tawano sara disimbolkan sebagai daunnya adat. Meskipun disebut sebagai pelengkap adat, tetapi masuk dalam kategori materi adat yang harus dipenuhi oleh keluarga pihak laki-laki. Tawano sara terdiri atas 8 atau 16 lembar sarung adat dan 1 lembar sarung plekat.

\section{Sara Peana}

Sara peana merupakan adat pengganti pengasuhan dan pemeliharaan bayi. Ini dilakukan dengan alasan bahwa perempuan yang akan dipinang telah dipelihara dengan susah payah oleh ibunya sejak kecil sampai dewasa. Merupakan sebuah kewajaran untuk membalas jasa tersebut dengan sejumlah benda (meskipun tentu saja materi tersebut tidak cukup untuk membalas jasa ibu) sebagai tanda terima kasih calon menantu kepada calon mertuanya yang telah menjaga dan memelihara calon istrinya.

Sara peana merupakan simbol ketulusan, rasa terima kasih dan kebahagiaan calon suami yang diungkapkan dengan cara penyerahan benda-benda tertentu. Benda-benda sara peana mencerminkan upaya yang dilakukan ibu ketika mengasuh dan merawat si gadis sewaktu bayi, seperti baskom tempat mandi bayi, gayung, lampu teplok sebagai alat penerang, kain sarung untuk menggendong dan kain untuk ganti pakaian ibu yang kena pipis bayinya. Pada dasarnya, bukan benda-benda adat tersebut yang menjadi fokus perhatian, tetapi makna ketulusan, rasa terima kasih dan penghargaan yang ingin ditonjolkan dalam ritus perkawinan.

Selain materi pokok adat di atas, penganut agama Islam juga menyediakan mahar untuk diberikan kepada calon istri. Mahar itu ditentukan sendiri oleh calon suami, tetapi pada umumnya masyarakat Tolaki mewujudkannya dalam bentuk seperangkat alat sholat. Meskipun ada saja tambahan lebih dari itu atau diganti dengan sejumlah uang ataupun wujud benda yang lain. Yang menjadi pertimbagan utama dalam adat perkawinan adalah tidak boleh kurang atau berubahnya materi adat pokok seperti yang sudah dijelaskan sebelumnya.

Pada tahap pertama, pelaksanaan perkawinan atau mowindahako merupakan otoritas lembaga adat ( pabitara dan tolea) atau juru bicara. Setelah acara adat selesai dilaksanakan, barulah diadakan perkawinan dengan akad nikah bagi yang beragama Islam dan pembaktian di gereja bagi yang beragama Kristen.

Upacara mowindahako dalam masyarakat Tolaki secara tertib melalui tahap-tahap sebagai berkut;

1. Sara mombependaehi, yaitu adat permohonan izin dan restu juru bicara adat laki-laki (tolea) kepada pemerintah untuk memulai acara mowindahako.

2. Membaramesi, yaitu pengantar kata juru bicara adat pihak laki-laki (tolea) kepada juru bicara adat pihak perempuan (pabitara), sekaligus permohonan izin untuk menyerahkan seserahan adat yang sudah ditetapkan sebelumnya.

3. Sara mowindahako, yaitu penunaian beban adat dari pihak laki-laki kepada pihak perempuan berupa materi pokok adat (puuno sara, tawao sara, sara peana, dan popolo)

4. Pelaksanaan akad nikah secara Islam yang diambil alih oleh petugas nikah. Pada tahap ini lembaga adat tidak terlibat dan sepenuhnya merupakan wewenang petugas nikah.

5. Resepsi pernikahan atau walimah.

Pada tahap penyerahan materi pokok adat dan popolo, ditunaikan pula kewajiban lain yang harus dipenuhi pihak laki-laki (jika masih ada), misalnya, tidak dipenuhinya kewajiban pada saat pertunangan, adanya pembayaran yang harus dilakukan jika calon mempelai perempuan mempunyai kakak yang belum menikah (moliasako), dan sebagainya. Moliasako artinya melewati, maka harus ada pembayaran khusus yang disebut dengan poliasako dalam bentuk cincin emas atau satu lembar kain sarung.

Setelah acara adat selesai dilaksanakan, juru bicara adat kemudian menyampaikan pengukuhan atau kata-kata penutup yang disebut mohue. Pada mohue ini dilakukan tulura 
pohue osara, artinya sumpah penutup adat yang pada intinya memohon kepada Tuhan agar mereka tidak terkena laknat akibat kesalahan pelaksanaan tahapan adat atau kata-kata yang tidak senonoh. Setelah rangkaian acara adat telah selesai dilaksanakan, maka petugas nikah mengambil alih acara dan menikahkan dengan cara agama. Tahap ini benar-benar murni pernikahan dengan tata cara agama. Sesudah itu, dilanjutkan dengan pembatalan wudhu. Suami harus memberikan sejumlah uang kepada para gadis yang menghalanginya masuk kamar istrinya yang disebut dengan teposuange walino. Pada acara terakhir, kedua pengantin disandingkan dipelaminan (mombokombedulu).

\section{Dinamika Konflik dalam Perkawinan Masyarakat Tolaki}

Beberapa bentuk perselisihan sosial dalam perkawinan masyarakat Tolaki dapat dijumpai dalam dua bentuk, yaitu a) tidak mendapatkan kesempatan yang sama; b) penolakan terhadap prosedur dan tata cara perkawinan. Berikut ini akan diuraikan satu persatu;

1. Tidak mendapatkan kesempatan yang sama

Aspirasi, kebutuhan, dan kepentingan menjadi alasan utama timbulnya konflik dalam masyarakat Tolaki. Setiap kelompok masyarakat menampakkan diri dalam situasi konflik karena adanya persepsi dan kepentingan yang berbeda. Tertutupnya kesempatan bagi salah satu pihak untuk mendapatkan peluang perlakuan yang sama muncul dalam wujud kesulitan menikahi perempuan dari kelas sosial atas. Meskipun dewasa ini peluang tersebut secara perlahan mulai longgar, namun persyaratan yang relatif berat masih tetap ada. Laki-laki yang ingin menikahi perempuan dari kelas sosial atas (anakia, misalnya) harus memenuhi sejumlah syarat yang ditetapkan oleh keluarga perempuan dan lembaga adat. Dipersempitnya peluang bagi level masyarakat kebanyakan (ata atau toonomotuo) untuk menikahi perempuan dari kelas sosial atas dengan adanya syarat perkawinan yang ditetapkan jauh melampaui kemampuan keluarga laki-laki. Tokoh adat umumnya berpendapat bahwa strata sosial masyarakat merupakan warisan nenek moyang yang secara turun temurun harus dijunjung tinggi.

2. Penolakan terhadap prosedur dan tatacara perkawinan

Asprasi dan kepentingan yang berbeda bisa mewujudkan diri dalam bentuk resistensi atau penolakan terhadap cara-cara yang dilakukan pihak lain. Penolakan terhadap prosedur dan tatacara perkawinan oleh pihak tertentu menunjukkan adanya konflik di dalamnya. Penolakan tersebut dilakukan terutama oleh laki-laki dari kelas sosial bawah terhadap syarat perkawinan yang dianggap berat, seperti pesta meriah, beras, sapi/kerbau, dan sejumlah uang yang harus dipenuhi.

Penolakan terhadap tacara perkawinan diwujudkan dalam bentuk kawin lari. Kawin lari tampaknya menunjukkan sebuah gerakan protes sosial oleh sebagian kelompok masyarakat bawah terhadap sistem yang ada. Stratifikasi masyarakat yang berkonsekwensi pada ketentuan syarat, materi adat yang berbeda menjadi alasan utama ditempuhnya jalan kawin lari. Meskipun dewasa ini persyaratan tersebut masih membuka peluang terjadinya negosiasi, tetapi akar persoalannya bukan pada kesanggupan atau ketidaksanggupan keluarga laki-laki dalam memenuhi persyaratan, tetapi justru pada pembedaan perlakuan (diskriminasi, marginalisasi, dan fragmentasi).

Penetapan syarat perkawinan yang berat menunjukan perlakuan diskriminatif dan fragmentatif diantara masyarakat. Penentuan syarat (naifnya, bukan merupakan pokok adat) cenderung merugikan masyarakat bawah dan menurut Sihombing sering terjadi terhadap kelompok yang lemah dan secara politis dan sosial tidak memiliki sarana tawar menawar. ${ }^{8}$ Syarat perkawinan tidak akan dipersoalkan, jika keberadaannya hanya sebagai tradisi yang

8 Justin M Sihombing, Kekerasan Terhadap Masyarakat Marginal, (Yogyakarta: Narasi, 2005), h. 94. 
memungkinkan peluang negosiasi antara keluarga kedua belah pihak, sebab boleh jadi syarat hanya merupakan simbol harapan dan keinginan untuk mempertinggi derajat dan martabat keluarga di mata masyarakat. Akan tetapi, syarat perkawinan bisa memicu konflik jika peluang untuk negosiasi tertutup sama sekali dan pengajuan syarat ini kemudian membawa akibat ketidakadilan pada keluarga laki-laki yang membuka peluang untuk menempuh jalan pintas (kawin lari, berhutang, dan sebagainya), sementara kawin lari sendiri dalam masyarakat Tolaki dianggap sebagai cara yang kurang baik dan terpuji.

Penolakan atau bahkan protes/kritik terhadap tatacara perkawinan merupakan instrumen atau koreksi terhadap kekuasaan dan sistem dalam upaya menciptakan proses integrasi dalam masyarakat, dan mereduksi segala bentuk dikriminisasi terhadap kelas sosial yang berbeda. Faruk menyebut kritik atau protes sosial adalah sebuah imperatif kultural yang diperlukan demi sebuah proses pemanusiaan manusia. ${ }^{9}$ Pembedaan perlakuan akibat kelas sosial yang berbeda inilah menjadi alasan ditempuhnya jalan kawin lari dan menjadi akar konflik yang sebenarnya.

Karena jamaknya persyaratan perkawinan yang relatif memberatkan menunjukkan legitimasi atas adanya perbedaan kelas sosial dan pembedaan perlakuan dalam masyarakat. Kelas sosial yang berbeda berakibat pada pembedaan perlakuan dan pengajuan persyaratan sesuai kelas sosial perempuan. Persyaratan perkawinan di luar materi pokok adat juga menunjukkan sebuah upaya pelanggengan kekuasaan bagi satu kelompok elit, yaitu kelas sosial atas.

Penetapan syarat perkawinan yang berat dibungkus dan membungkus kekuasaan kelompok elit merupakan upaya "penyadaran" yang sistemik kepada masyarakat bahwa mereka memiliki kedudukan yang lebih tinggi dibanding kelompok masyarakat lainnya. Penyadaran ini dilakukan secara samar dan tersembunyi dan oleh karena samar dan tidak mudah dideteksi, maka penyadaran akan perbedaan tersebut dianggap sebagai sesuatu yang alamiah dan wajar, padahal sesungguhnya bagi Bourdieu ini adalah sebuah bentuk kekerasan atau lebih tepatnya "kekerasan simbolis". ${ }^{10}$

Kewajaran atas perlakuan tersebut disebabkan oleh tatanan masyarakat yang cenderung menutup akses kelompok nirdominan untuk mendapat kesempatan yang sama dalam perkawinan. Akibatnya, diskriminasi dan fragmentasi tetap ada yang diwujudkan dalam bentuk beratnya syarat perkawinan. Hal ini menunjukkan bahwa kekerasan yang tersamar timbul karena adanya kekerasan struktural yang menimbun dan terjadi secara terus menerus dalam jangka waktu yang lama.

Terjadinya pertentangan sebagaimana diatas disebabkan oleh banyak hal tergantung atas sifat dan skala konflik. Konflik dalam perkawinan masyarakat Tolaki meliputi beberapa hal diantaranya; a) perbedaan kelas sosial, b) tidak ada legitimasi atas hak dan peluang yang sama, c) perbedaan kepentingan dalam perkawinan, d) dominasi elit tradisional.

\section{Perbedaan kelas sosial}

Terbaginya kelas sosial dalam masyarakat Tolaki yang terdiri atas: golongan anakia (bangsawan), toonomotuo (orang tua/pemilik negeri), dan ata (rakyat biasa/budak, membawa dampak sosial maupun psikologis diantara elemen masyarakat. Kelas sosial yang berbeda membawa konsekwensi pada tata aturan perkawinan, satu di antaranya adalah kesulitan pernikahan antara kelas sosial berbeda, terutama bagi laki-laki dari kelas sosial bawah dengan

\footnotetext{
${ }^{9}$ Lihat Mohtar Mas'oed, Kritik Sosial dalam Wacana Pembangunan, (Yogyakarta: UII Press, 1999),
} h. 36 .

\footnotetext{
${ }^{10}$ Lihat Haryatmoko, Etika Politik dan Kekuasaan, (Jakarta: Kompas, 2003).
} 
perempuan dari kelas sosial tinggi, penetapan materi adat sesuai dengan kelas sosial keluarga perempuan, dan penentuan syarat perkawinan sesuai status sosial keluarga perempuan. Status sosial perempuan yang akan dinikahi merupakan landasan pokok penentuan materi dan syarat perkawinan. Kelas sosial tidak hanya ditentukan oleh kedua orang tua perempuan semata, tetapi juga oleh keluarga besarnya (extend family). Oleh sebab itu, penentu kebijakan perkawinan bukan hanya kedua orang tua pasangan, tetapi juga keluarga besar.

Seorang laki-laki jika ingin menikahi perempuan dari golongan sosial atas (anakia) seringkali harus menemui kendala dengan adanya syarat perkawinan yang cukup memberatkan. Keluarga perempuan yang berasal dari kelas sosial tinggi berusaha untuk menjaga martabat, prestise, dan kehormatan keluarganya dengan menetapkan syarat yang relatif tinggi, dalam bentuk pesta meriah, beberapa ekor kerbau/sapi, sejumlah uang yang cukup banyak, dan beberapa liter beras. Materi adat yang ditetapkan sesuai kelas sosial masyarakat relatif tidak memberatkan, dalam arti dapat terjangkau oleh masyarakat dari kelas sosial manapun. Hal yang justru memberatkan adalah syarat adanya pesta, sejumlah uang, beberapa ekor sapi/kerbau, dan beras.

2. Tidak ada legitimasi atas peluang yang sama

Konflik dalam perkawinan bisa pula dipicu oleh tidak adanya legitimasi (pengakuan) atas hak dan kesempatan yang sama (Coser, 1956). Pengakuan atas kesempatan dan hak yang sama tidak didapatkan oleh golongan masyarakat dari kelas sosial bawah, sehingga keinginan seorang laki-laki dari kelas sosial tersebut untuk menikahi perempuan dari kelas sosial tinggi relatif lebih sulit, karena penetapan syarat yang berat. Syarat berat yang diajukan oleh keluarga perempuan biasa pula dilakukan sebagai upaya untuk menolak secara halus pernikahan tersebut.

3. Perbedaan kepentingan dalam perkawinan.

Dalam masyarakat Tolaki perkawinan tidak hanya diputuskan oleh calon mempelai dengan keluarganya, tetapi juga keluarga besar secara keseluruhan (extend family), lembaga adat, dan masyarakat. Konflik dalam perkawinan dapat pula terjadi karena benturan kepentingan berbagai pihak yang terlibat. Dominasi lembaga adat yang memperjuangkan kepentingan tetap langgengnya kewibawaan adat Sarano Tolaki bergandengan dengan kelompok masyarakat atas yang ingin mempertahankan martabat kebangsawanannya, akan mendapatkan benturan dengan kelompok masyarakat yang melihat perkawinan sebagai sunnah (melestarikan tradisi nabi) dan wadah pertemuan dua individu dan keluarga yang selevel, tanpa embel-embel kelas sosial.

Benturan kepentingan antara adat dan agama semakin terasa pada pemahaman tentang persepsi kesederajatan ( $k a f a ' a h)$ dalam perkawinan. Islam menetapkan kafa'ah atau kesederajatan sebagai salah satu syarat bukan secara sosial, tetapi pada kesederajatan dalam keberagamaan (Hasan, 1990: 34). Sementara itu, adat Tolaki melihat kesederajatan dalam perkawinan lebih pada aspek strata sosial. Maka, benturan kepentingan bisa terjadi yang memandang perkawinan dan segala permasalahannya dari sudut pandang dan kepentingan yang berbeda.

4. Dominasi lembaga adat

Konflik selalu terjalin erat dengan kekuasaan dan kekuasaan dalam level bagaimanapun menjadi alat pelenggang konflik, jika ada pemaksaan sistem yang melanggengkan kepentingan kekuasaan tersebut (status quo). Lembaga adat Sarano Tolaki sebagai penentu kebijakan tertinggi dalam masyarakat memiliki peran yang tidak kecil dalam menciptakan konflik, sebagaimana juga bisa menjadi penjamin stabilitas. Keputusan yang dilakukan oleh lembaga adat dalam beberapa kasus bisa saja tidak mengakomodasi aspirasi dan kebutuhan masyarakat bawah, dan pihak yang menjadi korban, misalnya kasus kawin lari pada pasangan yang sudah memiliki suami/istri, penentuan syarat dan materi adat perkawinan. 
Lembaga adat dalam menangani pasangan yang kawin lari harus menikahkan pasangan tersebut apapun kondisi dan latar belakangnya, sebab kawin lari menjadi alasan mutlak pernikahan harus dilangsungkan.

Dominasi lembaga adat yang bisa mencetuskan konflik juga bisa dijumpai dalam keputusan adat terhadap korban yang pasangannya berbawa lari dengan orang lain. Jika kasus kawin lari (perempuannya sudah memiliki suami) ditangani lembaga adat, maka suami tersebut harus tunduk pada ketentuan adat yang ditetapkan, berupa penetapan denda berlapis yang dibayarkan oleh laki-laki yang membawa lari istrinya. Suami sebelumnya tidak bisa memprotes keputusan lembaga adat, sebab jika itu dilakukan maka ia bisa jadi menukar posisinya yang tadinya tidak bersalah menjadi bersalah. Kesalahan tersebut diberikan sebab ia secara adat mengingkari keputusan lembaga adat Tolaki.

Pelanggengan kekuasaan oleh lembaga adat sebagai salah satu akar pemicu konflik juga terjadi dalam penetapan syarat dan materi adat perkawinan. Syarat perkawinan ditentukan oleh keluarga perempuan, terutama dari kelas sosial atas dan atas persetujuan lembaga adat. Kebijakan lembaga adat dalam penyelesaian syarat perkawinan bisa jadi akan menguntungkan pihak kelas sosial atas, jika persoalan ketidakmampuan keluarga laki-laki tidak menjadi pertimbangan.

Tradisi masyarakat Tolaki tidak bisa dipisahkan dari kalo sebagai simbol dominan dan dianggap sakral serta keramat. Kalo sebagai sentral adat selalu dihadirkan dalam setiap acara adat, termasuk perkawinan. Power yang dimiliki kalo sebagai simbol adat yang digunakan oleh para tokoh adat menjadi penentu kestabilan ataupun kegoncangan dalam masyarakat. Kalosara yang diperhadapkan kepada laki-laki atau perempuan yang dikhianati oleh pasangannya kawin lari dilakukan sebagai upaya peredam marah dan pencegahan tidak terjadinya tindakan berbahaya. Tetapi faktanya, upaya tersebut hanya sampai pada permukaan saja. Persoalan tersebut bisa menjadi perkara kriminal, jika pihak korban tetap tidak mampu meredam emosi, meskipun kepadanya sudah diperhadapkan kalo. Maka yang terjadi adalah saling kejar, bunuh membunuh, dan sebagainya.

Dominasi kelas yang berkuasa seperti yang diwakili oleh elit adat terhadap kelas yang dikuasai dibangun oleh konsensus. Konsensus atau penyesuaian terhadap keadaan yang ada disebabkan oleh tiga hal, yaitu rasa takut, karena terbiasa, dan karena kesadaran dan persetujuan. ${ }^{11}$ Penyesuaian terhadap keadaan sangat ditentukan oleh kondisi individu dan setting sosial yang melingkupinya. Kepatuhan untuk memenuhi syarat adat yang memberatkan bisa jadi disebabkan oleh karena kebiasaan dan tradisi yang sudah mengakar demikian lama atau bisa pula karena persetujuan dan kesepakatan, jika kedua belah pihak sama-sama diuntungkan oleh keputusan tersebut. Konsensus yang dibangun berdasarkan rasa takut dan kebiasaan lama atau tradisi terjadi pada istri atau suami yang ditinggal kawin lari oleh pasangannya dan diharuskan menerima ketentuan adat peredam marah. Dua kondisi tersebut (rasa takut dan kebiasaan) pada dasarnya merupakan pola-pola penerimaan yang dipaksakan.

Dominasi satu kelompok tertentu dalam tesis Bourdieu menunjukan kecenderungan terjadinya kekerasan simbolik, dimana dominasi tersebut dilembagakan lewat kesepakatan yang diberikan oleh si terdominasi terhadap dominan, dan hal ini berlangsung secara natural tanpa disadari oleh kaum yeng terdominasi. ${ }^{12}$ (Bourdieu, 2010: 50).Proses penyelesaian masalah dalam perkawinan seperti model arbitrase (otoritas lembaga adat) yang dilakukan

${ }^{11}$ Nezar Patria \& Andi Arief, Antonio Gramsci; Negara \& Hegemoni, (Yogyarakarta: Pustaka Pelajar, 2003), h. 125.

12 Pierre Bourdieu, Dominansi Maskulin (Pent. Stephanus Aswar Herwinarko). (Yogyakarta: Jalasutra, 2010), h. 50. 
sebagai upaya menjamin stablitas dan keteraturan masyarakat, bisa berakibat pada upaya penyelesaian konflik hanya sampai pada tingkat permukaan. Stabilitas dan integrasi yang terjadi dalam masyarakat bukan saja disebabkan oleh konsensus terhadap tata aturan yang sama-sama disetujui, tetapi karena adanya pemaksaan terhadap stabilitas tersebut. ${ }^{13}$ Yang terjadi sesungguhnya adalah upaya peredaman konflik, bukan penyelesaian konflik, sebab penyelesaian dilakukan hanya pada taraf gejala dan tidak pada akar konflik yang sebenarnya.

\section{Kekerasan Simbolik dalam Tradisi Perkawinan Tolaki}

Faktor-faktor yang menjadi penyebab terjadinya pertentangan dan konflik dalam perkawinan masyarakat Tolaki merupakan realitas dan entitas yang unik. Faktor-faktor tersebut jalin menjalin dalam hubungan sebab akibat. Satu hal bisa menjadi akibat bagi hal lainnya dan kemudian menjadi sebab atas tindakan selanjutnya. Fenomena teresebut digambarkan sebagai sebuah rangkaian kekerasan yang jalin menjalin dalam sebuah peristiwa tak berkesudahan. Realitas tersebut diposisikan Camara sebagai spiral kekerasan ${ }^{14}$.

Konflik muncul dari persepsi mengenai perbedaan kepentingan (perceived divergence of interest). ${ }^{15}$ Konflik antara satu golongan masyarakat dengan masyarakat lain dalam perkawinan disebabkan oleh persepsi akan adanya perbedaan kepentingan antara pihak-pihak yang terlibat. Hal ini bisa terjadi ketika salah satu pihak bisa jadi memiliki aspirasi yang bertentangan dengan aspirasi pihak lainnya. Dalam situasi demikian, hanya ada dua pihak yang berseberangan, yaitu pihak dominan dan subordinat. Penyebab konflik terletak pada perbedaan kepentingan dan tidak tersedianya alternatif yang bisa mengakomodasi kepentingan kedua belah pihak.

Faktor lain penyebab timbulnya konflik menurut Dahrendrof adalah perbedaan distribusi otoritas. Dahrendrof menjelaskan bahwa pihak dominan berusaha untuk mempertahankan status quo, sedangkan pihak subordinat berkeinginan untuk melakukan perubahan ${ }^{16}$. Dengan konsep yang tidak jauh berbeda, Coser mengemukakan bahwa konflik terjadi karena intensifikasi tekanan terhadap kelompok yang tidak dominan dan tidak adanya legitimasi terhadap distribusi hak-hak dalam masyarakat. ${ }^{17} \mathrm{Hal}$ ini dalam tesis Foucoult terjadi relasi antara yang superiorioritas dan inferiorioritas dan atara ekslusivitas dan inklusivitas. ${ }^{18}$

Pemaksaan kepentingan kelompok dominan dan legitimasi selalu saja menjadi faktor utama penyebab konflik. Kelompok dominan (elit) memiliki peran yang sangat besar dalam menjamin stabilitas maupun cetusan konflik dalam masyarakat. Kaum elit dalam menanamkan dominasinya menggunakan wacana psikologis yang tidak disadari oleh kelompok nirdominan sebagai sebuah pemaksaan dan penindasan, bahkan menganggapnya sebagai sebuah kewajaran saja. Sesungguhnya ini adalah sebuah bentuk kekerasan atau lebih

13 Ian Robertson, Sociology, Second Edtion, (London: Worth Publishers, 1981).

${ }^{14}$ Dom Helder Camara, Spiral Kekerasan, (Yogyakarta: Resist Book, 2005), h. xvii, dalam Peter Canolly (Ed), Aneka Pendekatan Studi Agama, (Yogyakarta: LkiS, 1999).

${ }^{15}$ Dean G Pruitt \& Jeffrey Z. Rubin 2004. Teori Koflik Sosial, (Yogyakarta: Pustaka Pelajar, 2004), h. 21 .

${ }^{16}$ Lihat George Ritzer \& Douglas J. Goodman, Teori Sosiologi Modern. (Jakarta: Pernada Media, 2003), h. 155.

${ }^{17}$ Lewis Coser, The Function of Social Conflicts, (London: Free Press of Glencoe, 1956).

18 Michel Foucault, Histoire De La Sexualite. Vol 1, La Volonte' de savoir, (Paris: Gallimard, 1976), h. 87 . 
tepatnya kekerasan terlembaga atau kekerasan struktural. ${ }^{19}$ Kekerasan terlembaga tidak terjadi secara kebetulan, tetapi didukung oleh bangunan sosial sebagai legitimasi atas kekuasaan. Legitimasi atas kekuasaan ini disebut dengan dominasi yang merupakan satu aspek penaklukan yang mengarahkan pada kekuatan hegemonik. ${ }^{20}$

Selain itu, faktor penyebab konflik adalah tidak adanya pengakuan (legitimasi) atas hak-hak yang sama dalam masyarakat. Tidak adanya pengakuan atas hak yang sama atau diskriminasi juga merupakan salah satu bentuk dari kekerasan struktural. Kekerasan struktural cenderung tidak dirasakan oleh korban kekerasan, karena tetap memperlihatkan stabilitas dalam kondisi tertentu dan tidak kasat mata. Dalam kekerasan struktural, penderita kekerasan mengalami proses pelemahan yang sistimatik (systematic dispowerment).

Perbedaan kelas sosial, tidak ada legitimasi atas peluang yang sama, perbedaan kepentingan, dan dominasi lembaga adat merupakan fenomena dalam perkawinan masyarakat Tolaki yang mengindikasikan terjadinya kekerasan struktural. Hal ini bisa terjadi karena kelompok yang lemah tidak merasakan sebagai sebuah kekerasan atau juga merasa dipaksa dan ditindas oleh kelompok dominan. Faktor-faktor sebagaimana dijelaskan di atas menurut Giddens merupakan dimensi strukturasi dalam masyarakat yang bisa melahirkan kekerasan struktural. ${ }^{21}$ Kondisi inilah yang menjadikan sistem sosial disfungsional dan cenderung melahirkan konflik. Galtung membagi kekerasan dalam dua jenis, yaitu kekerasan langsung (direct violence), dan kekerasan struktural (structural violence). ${ }^{22}$ Belakangan, ia juga menambahkan satu jenis kekerasan lainnya, yaitu kekerasan budaya (cultural violence). Sementara itu, Salmi membagi kekerasan dalam empat kategori, yaitu kekerasan langsung, kekerasan tidak langsung, kekerasan represif, dan kekerasan alienatif. ${ }^{23}$ Kasus penyebab konflik dan disfungsional dalam sistem masyarakat Tolaki merujuk pada bentuk kekerasan represif menurut kategori Salmi dan untuk definisi Galtung termasuk jenis kekerasan struktural. Kekerasan stuktural merujuk pada upaya yang sistematik yang dilakukan oleh struktur atau institusi sosial dalam bentuk penghalangan seseorang untuk mencapai potensi dan kemampuan dirinya secara total.

Brofenbrenner melihat kekerasan struktural bekerja dalam tiga sistem, yaitu sistem sosial-politik (the macrosystem), sistem sosial-environment (the mesosystem), dan sistem psikologikal (the microsystem). ${ }^{24}$ Dalam masyarakat Tolaki, dominasi elit adat dikategorikan sebagai satu sistem kekerasan psikologis yang terjadi secara samar. Secara psikologis, masyarakat (khususnya kelompok sosial bawah) dipengaruhi untuk tunduk dan patuh atas nama hukum dan peraturan secara halus. Kekerasan psikologis seperti ini memungkinkan terjadinya dominasi dan menurut Giddens merupakan salah satu dimensi strukturasi dalam masyarakat yang bisa menjadikan kekuasaan semakin langgeng. ${ }^{25}$ Dominasi ini akan semakin kental karena didukung oleh idiologi kalo sebagai simbol adat yang harus dijunjung tinggi oleh seluruh masyarakat Tolaki. Simbol sebagaimana diungkapkan oleh Firth dapat menjadi sarana untuk menegakkan tatanan sosial dan menggugah kepatuhan-

\footnotetext{
${ }^{19}$ Haryatmoko, Etika Politik dan Kekuasaan, (Jakarta: Kompas, 2003), h. 48.

${ }^{20}$ A. M. Yusuf, "Assituruseng: Hegemoni Budaya Dalam Praktik Politik dan Kekuasaan di Belawa", ETNOSIA: JURNAL ETNOGRAFI INDONESIA, Vol. 2, No. 1, (Juni 2017): 74-94.

${ }^{21}$ Anthony Giddens, Teori Strukturasi untuk Analisis Sosial, (Pasuruan: Pedati, 2003), h. 313.

22 Lihat Muller, "Peace

Education". $<$ http//www.dadlos.org/frieden_int/grundkurs_2/typologie.htm>. Diakses 13 April 2018.

23 Jamil Salmi, Violence and Democratic Society, (Yogyakarta: Pilar Media, 2005), h. 32-40.

24 Lihat Susan James, "Structural Violence: The Invisible Violence in Our Community". http//www.apha.confex.com/apha/129am/techprogram/paper 25670.htm>. Diakses 16 Mei 2018

${ }^{25}$ Lihat Haryatmoko, Etika Politik...
} 
kepatuhan. ${ }^{26}$ Maka, kalo dalam masyarakat Tolaki sebagai sentral adat dapat menjadi alat penjamin stabilitas dan preventif atas ketidakpatuhan anggota atasnya.

Simbol kalo bisa menjadi alat legitimasi untuk melemahkan posisi masyarakat bawah, jika itu digunakan untuk melanggengkan kekuasaan yang tidak berpihak pada kelompok masyarakat tertindas dan juga perlindungan sistematis terhadap kelompk sosial tertentu (bangsawan). Dalam kondisi demikian, kekerasan strukltural sangat mungkin terjadi, jika kelompok masyarakat tertentu dilemahkan potensi dan ditutup akses atas kebutuhan dasarnya dengan menggunakan simbol budaya (kalo).

Kekerasan struktural dimainkan secara samar dan tersembunyi lewat idiologi, bahasa, dan sebagainya. Idiologi dan keyakinan masyarakat Tolaki diwujudkan lewat kalo sebagai sentral adat Tolaki. Idiologi yang digunakan tokoh elit sebagai alat legitimasi atas kekuasaan menurut Galtung juga menjadi bentuk kekerasan budaya, karena menggunakan satu aspek budaya (idiologi) sebagai alat legitimasi terhadap kekerasan. ${ }^{27}$ Kekerasan budaya digunakan lewat idiologi atau aspek budaya lainnya untuk menjamin justifikasi atau legitimasi atas kekerasan langsung dan kekerasan struktural. Apapun bentuknya, setiap upaya penutupan akses terhadap individu untuk memperoleh kebutuhan dasarnya, baik fisik maupun psikis adalah suatu bentuk kekerasan.

Salah satu penyebab tetap berlangsungnya kekerasan struktural dalam masyarakat adalah sikap diam dan pasrah (pasitivisme). Sikap pasrah yang ditunjukkan oleh kelompok nirdominan sesungguhnya berasal dari situasi ketidakberdayaan yang melingkupi kehidupan mereka. Akibat dari pasivisme demikian adalah kekerasan dan ketidakadilan akan tetap langgeng, oleh sebab tidak adanya perlawanan dan menganggap kekerasan tersebut sebagai sebuah kewajaran. Suseno menganggap bahwa kekerasan dan ketidakadilan dilegalkan dan dipertahankan oleh sikap pasif dalam diri manusia itu sendiri. ${ }^{28}$

Kelompok elit yang bisa memainkan kekerasan struktural dalam masyarakat Tolaki adalah tokoh adat yang didukung oleh tatanan sosial lembaga adat sebagai kekuatan hukum informal dalam masyarakat Tolaki. Tokoh elit adat bisa menjadi penjamin kestabilan, keadilan, dan integrasi antara elemen dalam masyarakat, tetapi bisa juga memainkan dominasi dan otoritas atas nama peraturan dan stabilitas dalam bentuk kekerasan psikologis yang terlembagakan. Dalam banyak praktek adat masyarakat terdapat ketimpangan gender yang dilegitimasi secara kultur dan juga agama. Di masyarakat Suku Mboj NTB misalnya dimana laki-laki sebagai dipercayakan sebagai pemimpin ritual agama, sementara ritual adat cukup dipercayakan kepada sando perempuan. ${ }^{29}$ Begitu pula halnya yang terjadi dalam masyarakat Mentawai dimana perempuan Siberut di Mentawai melakukan resistensi terhadap dominasi laki-laki dalam banyak klaim-klaim kebenaran yang diciptakan sendiri oleh mereka. ${ }^{30}$

Konsensus dan penyesuaian terhadap sistem yang ada bisa jadi dibentuk oleh upaya kekuasaan (dominasi eli adat) untuk membentuk sikap ketertundukkan atau upaya untuk mengubah sikap perlawanan terhadap kekuasaan. Ketidakberdayaan yang ditunjukkan dalam sebuah konsensus dan kompromistis terjadi dalam kondisi-kondisi yang secara psikologis, sosial, politik, dan ekomomi berada pada posisi yang inferior, tidak stabil, dan relatif lebih

\footnotetext{
${ }^{26}$ Lihat F.W. Dillistone, The Power of Symbols, (Yogyakarta: Kanisius, 2002), h. 123.

${ }^{27}$ Lihat Frans-Magnis Suseno, Melawan Kekerasan Tanpa Kekerasan, (Yogyakarta: Pemeliharaan Kesehatan Remaja, 2002), h. 183.

${ }^{28}$ Frans-Magnis Suseno, Melawan Kekerasan ..., h. 179.

${ }^{29}$ Atik Triratnawati, "Pola Antenatal Care dan Health Seeking Behavior Ibu Hamil Suku Mbojo, Bima, Nusa Tenggara Barat”, Jurnal Mozaik Humaniora, Vol. 18, No. 19 Januari-Juni 2018) : 33-49.

${ }^{30}$ Maskota Defli, "Contemporary Mentawai Recapitulates Anchestry: The Position of Women in Siberut Society”, Jurnal Humaniora, Vol. 25, No. 1 (Februari 2013): 14-24.
} 
dependen atas kekuasaan itu sendiri. Posisi inferioritas, ketidakstabilan, dan depedensi yang dimiliki oleh kelompok nirdominan, baik secara psikologis, sosial, politik, maupun ekonomi merupakan faktor utama terjadinya kondisi pemaksanaan sikap untuk tunduk dan patuh atas nama peraturan dan hukum. Hukum dan peraturan dalam masyarakat secara general hampir dapat dipastikan dimotori oleh tokoh elit dan didukung pula oleh kelompok bangawan yang hendak melanggengkan kekuasaan, dan dalam masyarakat Tolaki elit tersebut adalah lembaga adat.

Kestabilan dan integrasi dalam masyarakat dengan demikian sangat bergantung pada kaum elit adat. Tajima memaparkan bahwa konflik dapat direduksi untuk tidak merebak dan meninggi lewat peran para elit. ${ }^{31}$ Berdasarkan hasil penelitiannya atas eskalasi konflik Lampung, Tajima menyimpulkan bahwa peran elit dapat mereduksi konflik lewat upayanya dalam empat hal, yaitu (a) interaksi yang positif terhadap identitas lainnya; (b) semangat untuk bekerja sama; (c) keinginan dan kemauan untuk mengubah persepsi terhadap perjuangan dan norma yang berkobar-kobar; dan (d) pemahaman yang jelas bahwa terdapat hubungan antara norma-norma yang melingkupi perilaku individu dan eskalasi konflik. Keempat usaha yang dikemukakan diatas merupakan kondisi-kondisi yang memungkinkan kestabilan dan integritas dalam masyarakat dapat terjamin dan bermakna lebih baik.

Kekerasan struktural yang terjadi dalam masyarakat Tolaki secara langsung dan fisik tidak dirasakan sebagai sebuah kekerasan. Ia boleh jadi dilegitimasi oleh dalam bentuk social logic sehingga ia terlegitimasi secara sosial dan kultur atas nama keharmonisan dan penyelesaian masalah, Dalam tataran ini, kekerasan menjadi hal yang niscaya. ${ }^{32}$ Kekerasan ini berlangsung secara samar dan terbungkus rapi oleh keteraturan sistem dan perlakuan yang sudah biasa dirasakan oleh masyarakat. Biarpun berlangsung secara samar, tetapi dampak yang ditimbulkannya tidak lebih kecil dari kekerasan langsung (direct violence), bahkan lebih berbahaya. Winter \& Leighton menegaskan bahwa kekerasan struktural berpotensi besar meletupkan api kekerasan langsung dan jika ini terjadi efeknya akan sangat mengerikan. ${ }^{33}$

Bagaimanapun, konflik tidak dapat diabaikan dalam masyarakat, sebab integritas tidak akan tercipta dengan mengabaikan konflik. Narayana menegaskan bahwa stabilitas yang mapan tidak akan didapatkan hanya lewat penerimaan semu terhadap nilainilai yang diberikan oleh tradisi, sistem sosial, ataupun agama. ${ }^{34}$ Tesis tersebut diperkuat oleh Appleby dengan mengatakan bahwa kondisi damai bukannya tanpa konflik. ${ }^{35}$ Baumana memperingatkan bahwa integritas dan penerimaan tanpa kritik terhadap kepercayaan dan kebiasaan bisa jadi menimbulkan efek yang menakutan dan mengerikan. ${ }^{36}$ Upaya

31 Yuhki Tajima, Mobilizing for Violence: the Escalation and Limitation of Identity Conflicts, (Jakarta: World Bank office, 2004), h. 23.

${ }^{32}$ Sarmin, "Ruang dan Kultur kekerasan Domestik; Pengalaman Perempuan Madura di Kemayoran baru Surabaya", Jurnal Humaniora, Vol. 20, No. 1 (Februari 2008): 38-50; Lihat pula Rosmala Nur, "Nilai-Nilai Budaya Lokal dan Kekerasan terhadap Perempuan masa Hamil di Kabupaten Donggala, Sulawesi Tengah", Jurnal Humaniora, Vol. 24, No. 1 (Februari 2012): 37-49.

33 Winter, Deborah Du nann \& Dana Leighton. "Structural Violence Introduction".

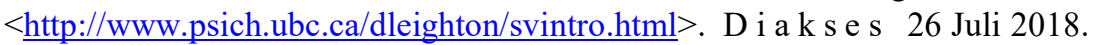

34 Narayana, Badri. "Itegration Without Conflict Possible?" Dalam Badri Pastimes. $<$ http//badri.blogspot.com/2005/03/integration-without-conflict-possible.html $>$. Diakses 16 Agustus 2018.

${ }^{35}$ R. Scott Appleby, The Ambivalence of The Sacred, (New York: Carnegie Corporation, 2000), h. 18.

36 Lihat Saughstad, Andreas. "Structural \& The Autonomy of Morals". Dalam GO Inside. <http://goinside.com/01/6/morals.html>. D i a k s e s 18 Agustus 2018. 
penyelesaian konflik bisa tetap dilakukan dalam rangka menjaga tatanan struktur masyarakat yang arif dengan cara-cara yang adil dan tidak merugikan satu pihak. Peran tersebut ada ditangan para pemimpin agama, pemimpin adat, atau tokoh masyarakat lainnya.

\section{E. Penutup}

Stabilitas diperlukan dalam masyarakat untuk menjaga batas konflik jangan sampai menggoncangkan tatanan sosial masyarakat, tetapi stabilitas yang terlalu banyak juga dapat bersifat disfungsional, karena keputusan untuk menolak konflik justru menjadi pemicu awal konflik itu sendiri. Maka, yang terjadi adalah stabilitas yang semu, karena bibit konflik tetap dibiarkan bertunas. Konflik dan pertentangan yang terjadi dalam tradisi perkawinan masyarakat Tolaki membingkai satu fakta telah terjadi kekerasan simbolik atau kekerasan struktural.

Kekerasan simbolik ini disebabkan salah satunya oleh konflik laten yang tidak langsung terlihat secara kasat mata, sebab ia bekerja di dalam konstruksi kultural atas nama stabilitas dan keteraturan dalam masyarakat. Korban tidak merasakan langsung sebagai sebuah kekerasan, oleh karena ada proses pelemahan secara sistematik (systematic dispowerment). Ia disebut sebagai kekerasan struktural yang berlindung dibalik simbol-simbol adat dan tradisi. Kekerasan simbolik atau kekerasan struktural dalam kasus perkawinan masyarakat Tolaki di Sulawesi Tenggara dapat ditemui dalam beberapa bentuk, yaitu pertama, tidak mendapatkan kesempatan yang sama bagi semua level masyarakat; dan kedua penolakan terhadap prosedur dan tatacara perkawinan. Kondisi ini disebabkan oleh perbedaan kelas sosial dalam masyarakat Tolaki yang berkonsekwensi pada perbedaan penetapan materi dan syarat perkawinan; tidak ada legitimasi atas hak dan peluang yang sama untuk menikahi perempuan dari kelas sosial manapun; perbedaan kepentingan antara pihak-pihak yang terlibat dalam perkawinan; dan dominasi elit adat yang secara langsung memiliki kontribusi yang sangat besar dalam perkawinan.

Bagaimanapun, perbedaan dan pertentangan kepentingan, aspirasi, dan kebutuhan sebagai akar konflik antara anggota masyarakat membawa perubahan besar dalam sistem dan struktur masyarakat. Perbedaan level sosial masyarakat yang berimplikasi pada pembedaan perlakuan membawa dampak semakin longgarnya sistem dan struktur sosial masyarakat Tolaki yang semula mapan. Kelonggaran strata sosial masyarakat berdampak pada terbukanya peluang yang sama bagi semua kelompok masyarakat dalam mendapatkan pasangan hidup.

\section{DAFTAR PUSTAKA}

Appleby, R. Scott. The Ambivalence of The Sacred. New York: Carnegie Corporation, 2000 .

Bourdieu, Piere. Dominansi Maskulin (Pent. Stephanus Aswar Herwinarko). Yogyakarta: Jalasutra, 2010.

Camara, Dom Helder. Spiral Kekerasan. Yogyakarta: Resist Book, 2005.

Canolly, Peter (Ed). Aneka Pendekatan Studi Agama. Yogyakarta: LkiS, 1999.

Coser, Lewis. The Function of Social Conflicts. London: Free Press of Glencoe, 1956.

Maskota Defli, "Contemporary Mentawai Recapitulates Anchestry: The Position of Women in Siberut Society", Jurnal Humaniora, Vol. 25, No. 1 (Februari 2013): 14-24.

Dillistone, F.W. The Power of Symbols. Yogyakarta: Kanisius, 2002. 
Foucault, Michel. Histoire De La Sexualite. Vol 1, La Volonte' de savoir. Paris: Gallimard, 1976.

Giddens, Anthony. Teori Strukturasi untuk Analisis Sosial. Pasuruan: Pedati, 2003.

Hamdi, Saipul. “Tuan Guru, Otoritas, Politik Dan Reproduksi Kekerasan-Ritual Dalam Konflik Nahdlatul Wathan Di Lombok NTB”. Tt. Tp.

Haryatmoko. Etika Politik dan Kekuasaan. Jakarta: Kompas, 2003.

------------. "Menyingkap Kepalsuan Budaya Penguasa”. BASIS. No. 11-12, (NovemberDesember, 2003).

Hefni, Moh. "Tradisi Mawlid Dan Kekuasaan Simbolik Kyai Di Madura”. Jurnal Nuansa, Vol 10, No. 2 (Juli-Desember, 2013): 314-334.

Mas'oed, Mohtar. Kritik Sosial dalam Wacana Pembangunan. Yogyakarta: UII Press, 1999.

Nur, Rosmala. "Nilai-Nilai Budaya Lokal dan Kekerasan terhadap Perempuan masa Hamil di Kabupaten Donggala, Sulawesi Tengah", Jurnal Humaniora, Vol. 24, No. 1 (Februari 2012): 37-49.

Patria, Nezar \& Andi Arief. Antonio Gramsci; Negara \& Hegemoni. Yogyarakarta: Pustaka Pelajar, 2003.

Pruitt, Dean G \& Jeffrey Z. Rubin. Teori Koflik Sosial. Yogyakarta: Pustaka Pelajar, 2004.

Rais, Muhammad. "Hegemoni Elit Dalam Ritus Agama Lokal: Studi Keberagamaan Masyarakat Bugis Bone Sulawesi Selatan". Jurnal el-Harakah Vol. 12, No. 2 (2010): 99-119.

Riches, D, “The Phenomenon of Violence” Dalam The Anthropology of Violence, disunting oleh D. Riches, (Oxford: Blackwell, 1986).

Ritzer, George \& Douglas J. Goodman. Teori Sosiologi Modern. Jakarta: Pernada Media, 2003.

Robertson, Ian. Sociology. Second Edtion. London: Worth Publishers, 1981.

Rozaki, Abdur. Social Origin dan Politik Kuasa Blater di Madura". Kyoto Review of Southeast Asia. 12 Nov 2009, http:// kyotoreview.org/issue-11/the-social-origins-and-political-powerofblaters-thugs-in-madura/, accessed 28 Oct 2018.

Salmi, Jamil. Violence and Democratic Society. Yogyakarta: Pilar Media, 2005.

Santoso, Thomas. Teori-Teori Kekerasan. Jakarta: Ghalia Indonesia, 2002.

Sarmin, "Ruang dan Kultur kekerasan Domestik; Pengalaman Perempuan Madura di Kemayoran baru Surabaya", Jurnal Humaniora, Vol. 20, No. 1 (Februari 2008): 3850 . 
Schroder, I.W dan B.E. Schmidt. 2001. "Introduction: Violence Imaginaries and Violence Practice. Dalam Anthropology of Violence and Conflict, disunting oleh I.W. Schmidt dan B.E. Schroder. London: Routledge, 2001.

Sihombing, Justin M. Kekerasan Terhadap Masyarakat Marginal. Yogyakarta: Narasi, 2005.

Suseno, Frans-Magnis. Melawan Kekerasan Tanpa Kekerasan. Yogyakarta: Pemeliharaan Kesehatan Remaja, 2002.

Tajima, Yuhki. 2004. Mobilizing for Violence: the Escalation and Limitation of Identity Conflicts. Jakarta: World Bank office.

Tarimana, Abdur Rauf. 1985. Kalo Sebagai Fokus Kebudayaan Tolaki. Disertasi. Jakarta: Universitas Indonesia.

Tim. Adat dan Upacara Perkawinan Daerah Sulawesi Tenggara. Jakarta: Proyek Penelitian dan Pencatatan Kebudayaan Daerah Sulawesi Tenggara, 1978/1979.

Triratnawati, Atik, "Pola Antenatal Care dan Health Seeking Behavior Ibu Hamil Suku Mbojo, Bima, Nusa Tenggara Barat", Jurnal Mozaik Humaniora, Vol. 18, No. 19 Januari-Juni 2018): 33-49.

Yusuf, A.M. "Assituruseng: Hegemoni Budaya Dalam Praktik Politik dan Kekuasaan di Belawa”, ETNOSIA: JURNAL ETNOGRAFI INDONESIA, Vol. 2, No. 1, (Juni 2017): 74-94.

\section{Website:}

James, Susan. "Structural Violence: The invisible Violence in Our Community". $<$ http//www.apha.confex.com/apha/129am/techprogram/paper 25670.htm>. Diakses 16 Mei 2018.

Muller,

Ragnar.

"Peace

Education". $<$ http//www.dadlos.org/frieden_int/grundkurs_2/typologie.htm $>$. Diakses 13 April 2018.

Narayana, Badri. "Itegration Without Conflict Possible?" Dalam Badri Pastimes. $<$ http//badri.blogspot.com/2005/03/integration-without-conflict-possible.html $>$.

Diakses 16 Agustus 2018.

Saughstad, Andreas. "Structural \& The Autonomy of Morals". Dalam GO Inside. $\leq$ http://goinside.com/01/6/morals.html>. Diaks es 18 Agustus 2018.

Winter, Deborah Du nann \& Dana Leighton. "Structural Violence Introduction". $<$ http://www.psich.ubc.ca/dleighton/svintro.html $>$. D i a k s e s 26 Juli 2018. 